\title{
Employment growth constraints of informal enterprises in Diepsloot, Johannesburg
}

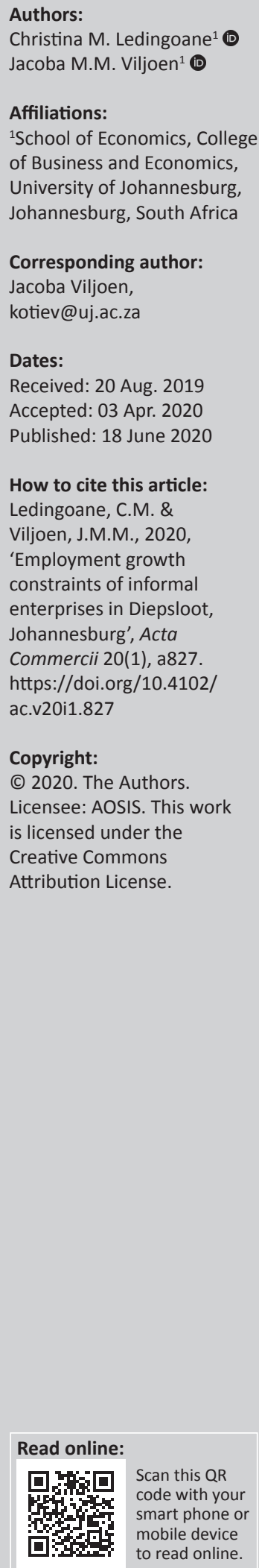

Orientation: Informal enterprises in South Africa's townships play an important role in employment creation and social protection. While some informal enterprises in inner cities grow, those in townships experience stagnant growth.

Research purpose: The aim was to identify and analyse the internal and external growth constraints, regarding employment growth, of informal enterprises in Diepsloot, Soweto.

Motivation for the study: Knowledge of internal and external growth constraints can inform policymakers on aspects that needs attention in assisting informal enterprises to realise their growth potential.

Research design, approach and method: A quantitative research approach was followed. Primary data were collected from 300 informal enterprises using a convenience sampling technique and structured questionnaire. Descriptive statistics, a matrix analysis and logistic regression models were used to analyse the data

Main findings: The statistically significant growth constraints faced by informal enterprises in Diepsloot are external constraints over which the owner or manager has no control. Local authorities have an important role to play in the growth of informal enterprises.

Practical/managerial implications: Managers need skills and training to manage the external growth constraints. Local authorities should also provide proper infrastructure, public services and increased security. An alternative source of funding, with the ease of access of microlender financing but at the rates of commercial bank lending, should be investigated.

Contribution/value-add: This study focuses on the growth constraints of informal enterprises in a township offering a wide range of goods and services. The increase in the number of employees is used as the measure for the enterprises' growth.

Keywords: Informal economy; township; SMMEs; employment growth; informal enterprises; growth constraint.

\section{Introduction}

The term 'informal' refers to employers and workers who make a living or supplement their earnings outside the formal economy (Edusah 2013:178). Informal non-agricultural activities play an important role in economic development and job creation in many African countries (Edusah 2013:177).

Many South Africans who cannot find employment in the formal economy also turn to the informal economy.

However, compared to other middle-income countries, South Africa's informal economy is much smaller (Lloyd \& Leibbrandt 2018:152). Between January 2008 and June 2016, only 16\% of those employed were employed in the informal economy (Lloyd \& Leibbrandt 2018:152). According to Statistics South Africa (StatsSA), informal enterprises generated 2.0 million jobs in 2005, 2.4 million jobs in 2008, 2.6 million jobs in 2015, and 2.7 million jobs in 2017 (StatsSA 2017:4). In 2014, 1.4 million were owners and 1.1 million were employees (Rogan \& Skinner 2018:151).

Informal sector enterprises are small micro enterprises but have a remarkable per-job impact on poverty (Fourie 2018a:19). Cichello and Rogan (2018:228) state that 'losing or gaining informal sector jobs has the same effect on poverty as losing or gaining formal sector jobs'.

Some people believe that a country's informal economy will disappear as its economy develops. However, evidence shows that the informal economy will not disappear and is increasing even in 
developed countries (Fourie 2018b:104; Hassan 2013:7). According to an Organisation for Economic Co-operation and Development (OECD) study in 2009 by Jütting and Laiglesia (2009:17-27), the growth in informal employment also increased in South-east Asia and Latin America over the last 30 years. Jütting and Laiglesia further found that informal employment is increasingly viewed as being normal even in middle and high-income countries and is viable and dynamic in many parts of the world (Hassan 2013:7). Informal enterprises, therefore, globally play an important role in employment creation and social protection.

Although the informal sector provides jobs, livelihoods, and income for millions of workers and enterprise owners, it has 'largely been missing from economic analysis and policy discourse - not only in South Africa but internationally' (Fourie 2018a:10). However, in some countries such as Thailand and India, home-based enterprises are protected. Street vendors in Ghana and India are regulated, and their markets have been upgraded with the help of municipalities (Kumar 2012). In Bhubaneshwar, the capital of Odisha (India), private companies finance the infrastructure for street traders in exchange for advertising space (Kumar 2012).

Informal enterprises can be categorised as either subsistence, survivalist or growth-oriented enterprises (Grimm, Knorringa \& Lay 2012:1353). In South Africa, the majority (73\%) of the informal enterprises are subsistence or survivalist enterprises (Hadebe 2010:1; Makaluza \& Burger 2018:19) that provide income for those unable to find regular wage employment (Hadebe 2010:1). According to Rogerson (1996:173), survival enterprises operate in areas with low market potential (township areas), whereas growth enterprises operate in areas where there is greater economic potential (usually in inner cities). Rogerson argues that some informal enterprises in inner cities grow in size, while those in townships experience stagnant growth. Morris and Pitt (1995:84) also found that most informal businesses in townships were subsistence enterprises but believed there were some that were more dynamic with unlimited entrepreneurial potential.

Although people are eager to start informal enterprises, more than $40 \%$ do not survive more than six months (Lloyd \& Leibbrandt 2018:453). The reasons for starting informal enterprises range from unemployment, low prospects for getting a job quickly and profit opportunity for entrepreneurs (Lloyd \& Leibbrandt 2018:157).

The majority of the unemployed people who need to benefit from growth in the informal enterprises reside in townships. This calls for the protection of informal sector jobs (Cichello \& Rogan 2018:228) and therefore necessitates an investigation into the constraints faced by informal enterprises in townships. Hadebe (2010:2) believes that factors that influence township informal enterprise growth have not been sufficiently investigated and need further investigation. Most previous studies focus on informal enterprises in inner cities and ignore township informal enterprises (Hadebe 2010:1). Little research exists on informal enterprises and owners of these informal enterprises (Lloyd \& Leibbrandt 2018:151). Grant (2010:609) states that 'township economies are not being conceptualised adequately' and need specific interventions separate from those for informal enterprises in urban areas and cities. Strategies to support informal township enterprises should acknowledge their different social, spatial and economic potential and needs. This requires sustained support from public and private development entities (Department of Economic Development 2016:65). Research on township informal enterprises is therefore crucial.

This study intends to identify and analyse the factors that constrain the growth of a wide range of informal enterprises in townships. Both internal constraints (factors arising from the characteristics within the business) and external constraints (factors arising from the environment in which the business operates) will be investigated. The next section outlines the conceptual framework of the study.

\section{Conceptual framework}

This article uses an adapted version of the United States Agency for International Development (USAID) (2005:5) funnel model, shown in Figure 1, to demarcate internal and external factors that might affect the growth of informal enterprises in Diepsloot, Johannesburg. The funnel model includes contextual factors related to the institutional, social capital, social exclusion and human capital theories.

Internal factors refer to business operational factors that are typically controllable and that arise, among others, from the education, knowledge and skills of managers and employees. External factors emanate from outside the enterprise as a result of the activities of other agents in the markets like suppliers, customers, competitors and government institutions (Hassan 2013:12). External factors are usually uncontrollable, but manageable, and are explained by the institutional, social capital and social exclusion theories.

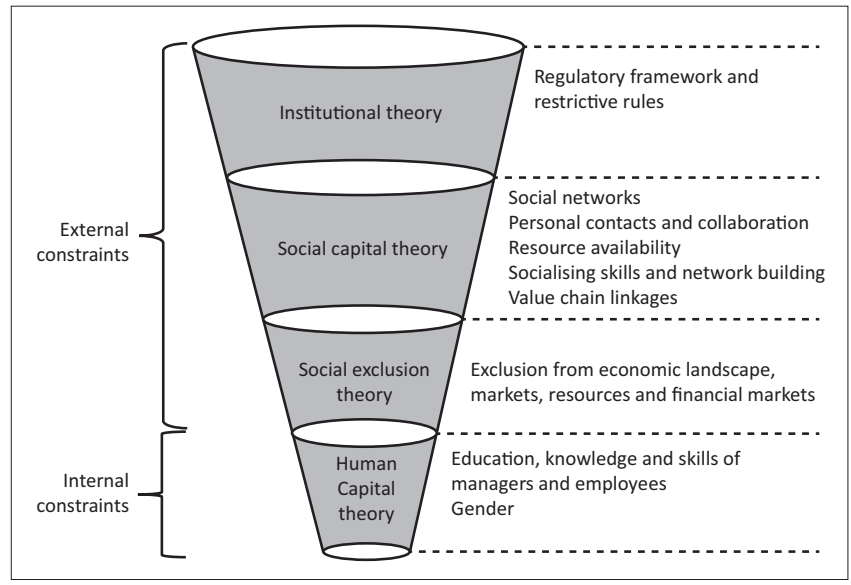

Source: Own illustration based on a study by USAID (United States Agency for International Development), 2005, Understanding micro and small enterprises growth, Micro reports no. 36, p. 5, viewed 18 December 2017, from http://www.microLINKS.org

FIGURE 1: Key factors hindering the growth of informal enterprises. 


\section{Institutional theory}

The institutional theory discusses the impact of government and non-government institutions, responsible for formulating and implementing rules, on informal enterprise growth (OECD 2003:3). Government institutions attempt to reduce enterprise risks, stemming from economic uncertainty, by creating an adequate regulatory framework (Hassan 2013:7; North 1993:2).

Irregularities between laws and regulations for formal institutions and the norms, values and codes of conduct in informal institutions explain why some entrepreneurs opt to operate in the informal sector (Welter, Smallbone \& Pobol 2015:1). Informal enterprises are usually small, not registered as an enterprise, do not pay taxes, use traditional and labourintensive technologies and do not keep accounting records. Entry into the informal economy is usually easier than into the formal economy (De Beer, Fu \& Wunsch-Vincent 2013:3; Grabrucker, Grimm \& Roubaus 2018:49), but being informal excludes them from many business opportunities. Weak legal and institutional frameworks characterise informality, and the laws and policies are not effectively implemented (ILO n.d.:2).

\section{Social capital theory}

The social capital theory analyses factors that affect the growth of an informal enterprise, through the lens of social networks. Social capital depends on a person's contacts, people's support and resource availability (De Graaf \& Flaph 1988:462). Kondowe (2013:16) states that a requirement for enterprise growth is secure social networks. Most owners or managers of informal enterprises do not have socialising opportunities, skills and knowledge to collaborate and build networks for entrepreneurial growth.

Value chain linkages are also a driver for small and micro enterprise (MSE) growth. These linkages have direct effects on the growth of enterprises through the formation of vertical linkages between buyers and their suppliers, and horizontal linkages between the small enterprises themselves (USAID $2005: 5,11)$. Value chains are also necessary for the transfer of technology, skills or finance, which affect the growth of enterprises directly (USAID 2005:5).

\section{Social exclusion theory}

The social exclusion theory provides deeper insights into informal enterprise marginalisation experiences and explains the effect of interlinking and mutually reinforcing problems in an area, like unemployment, discrimination, poor skills, low incomes and crime, that lead to other exclusions. According to Rann in Mathieson et al. (2008:12), an interplay of harsh, difficult and unjust economic conditions and social environments and insensitive government policies leads to social exclusion. Rogerson (2003:20) and Hassan (2013:4) confirm that the mere fact that an enterprise is informal and located in a specific area excludes them from the economic landscape, access to markets, market activities and resources that could grow the enterprise.

\section{Human capital theory}

The human capital theory explains the human subject in an enterprise who takes charge of the economic activities such as production, consumption, and transactions. Human capital endowments correlate with enterprise growth as they contribute to production through knowledge, skills, attitudes, capabilities, aptitudes and other acquired traits (Kondowe 2013:15). Human capital consists of different types of skills like personal, technical, entrepreneurial, business operations and management skills that can be acquired through education and training (Kondowe 2013:15; Smith \& Perks 2006:16). In most cases, informal enterprise owners, managers, supervisors, and employees do not possess the education and skills required to perform critical tasks. The lack of these characteristics constrains the growth of informal enterprises (Fadahunsi 2012:106).

\section{Empirical literature}

The focus of the empirical literature is to highlight the results of previous studies on the variables used in the data analysis.

\section{Stringent regulations and regulatory framework}

De Soto (1989:1) and Fatoki (2014:31) state that the stringent regulations and regulatory framework in which informal enterprises operate are restrictive and act as growth constraints to informal enterprises. Lack of legitimate and serviced trading spaces for unregistered informal enterprises pose a significant growth constraint for informal street traders in the cities of Johannesburg and Cape Town as well as informal enterprises in Diepsloot (Berry 2009:41; Sandeep 2014:202; Ukukhula 2003:9). Cupido (2002:1) agrees that informal enterprises often struggle to secure an area from which to operate. Hadebe (2010:3) indicates that most informal enterprises operate from home stands because they do not own property, trading space or stands. Ukukhula (2003:3) states that in the City of Cape Town, anyone wanting to access an area of operation must have a South African identity document and have a registered enterprise. This requirement excludes most informal enterprises from operating in business viable trading areas and makes them inaccessible to customers, potential partners and suppliers (Berry 2009:10). Informal enterprise owners are therefore deterred from making growth-enabling investments because of stringent regulations (USAID 2005:8).

\section{Access to financial markets}

A study by Kondowe (2013:2), among youth informal enterprise owners and four financial service providers in Cape Town, found that it is difficult for informal enterprises to secure capital from the private sector because of their informality. A study by Hassan (2013:9) also shows that micro, small and medium enterprises (MSMEs) in South Africa's 
townships are less likely to have bank accounts and their credit penetration is generally low. The lack of property rights and assets that can serve as collateral by informal enterprise owners makes the sourcing of capital difficult (Sparks \& Barnett 2010:6). Without collateral, lenders charge much higher interest rates, making it difficult for informal enterprises to obtain the necessary capital for either initiating new enterprises or expanding existing ones (Kondowe 2013:21). Informal enterprise owners have to find alternative ways to source capital to start or invest in their enterprises such as loans from informal sources, including family or informal moneylenders. Informal moneylenders, commonly referred to as 'loans sharks', charge inflated interest rates causing the informal enterprises' owners to struggle to repay their debt (Willemse 2011:8). Hassan further points out that the difficulty in accessing finance increases the vulnerability and economic exclusion of township entrepreneurs. Informal enterprises are therefore caught in a vicious cycle of informality.

\section{Value chain linkages}

Evidence by Chebelyon-Dalizu et al. (2010:10) among spaza shop owners showed that most of these shops have a weak value chain and that the lack of a consistent distribution system, and getting the goods from suppliers to their shops, serves as a significant growth constraint. In some cases, suppliers deliver products to informal shops directly but other suppliers hire independent logistics service providers to deliver goods to these shops. Most informal shop owners have to use public transport like taxis and buses to buy their stock from suppliers (Chebelyon-Dalizu et al. 2010:14). A weak value chain increases transaction costs, making products more expensive, hindering competitive pricing and resulting in a shrinking customer base (USAID 2005:5).

\section{Exclusion from markets}

Evidence from Woodward et al. (2011:67) and Hassan (2013:10) indicates that competition from shopping malls and supermarkets in townships also limits the informal enterprises' market size, income and growth prospects as the shopping malls attract most customers. Woodward et al. (2011:83), however, state that in South Africa informal enterprises and shopping malls can coexist as informal enterprises serve as convenience stores and are in closer proximity to their customers. They further sell smaller quantities, making it a cheaper option for the poor, and operate at convenient hours.

\section{Social capital and business network connections}

Informal enterprise owners are also intimidated and affected by foreign-owned enterprises. Foreign-owned enterprises usually have more social capital in the form of business network connections and have high-turnover and lowmargin strategies that translate into lower prices and more clients (Abdi 2011:700; Hassan 2013:16, 19). Evidence shows that a lack of inter-enterprise cooperation among informal enterprises as a result of competitiveness and jealousy jeopardises their ability to increase or maintain their income and profit levels (Bear, Tladi, Pedro \& Bradnum 2005:17; Willemse 2011:9). Bear et al. (2005:17) also emphasise the importance of informal enterprise owners to organise themselves. Chebelyon-Dalizu et al. (2010:12) also stress that approaching suppliers collaboratively can benefit informal enterprises as they can collectively bargain for discounted prices, enabling them to provide their customers with more competitive prices.

\section{Social environment}

The high crime level is one of the most significant growth constraints for informal enterprises (The South African Presidency 2008:7). The location of informal enterprises determines the level of crime. Informal enterprises located in townships face the highest rates of crime and lack protection against crime. Mengistae (2014:202) identified crime in Diepsloot as one of the most considerable growth constraints to informal enterprises. The cash-based nature of informal enterprises makes them appealing targets to criminals (Chebelyon-Dalizu et al. 2010:12-14). Chebelyon-Dalizu et al . (2010:13) found that most of the informal enterprises in their study have reported break-ins.

\section{Infrastructure}

According to Willemse (2011:9), the lack of infrastructure can have a negative impact on the informal enterprises' ability to operate their business and therefore their growth. This infrastructure includes access to roads and efficient and affordable public transport. Access to banks and post offices is essential for their financial needs. Infrastructure provided by municipalities like water, electricity and sewerage facilities are also important services that impact on the informal enterprises (Willemse 2011:9). Erastus, Stephen and Abdullai (2014:30) found that the lack of access to public services and delays in the delivery of public services impede the enterprises' growth.

\section{Technology}

Informal enterprises are further excluded from the use of technology as they are unable to accumulate the necessary capital to invest in technology (De Beer et al. 2013:4). Their production is usually labour intensive using low-skilled workers and simple technology.

\section{Education, knowledge, and skills of managers and employees}

Smith and Perks (2006:1) determined that most informal enterprise owners have limited entrepreneurial skills, mainly resulting from a lack of formal education and training. Many studies (Chebelyon-Dalizu et al. 2010:13; Kondowe 2013:1; Rwigema \& Karungu 1999:15) have established that a lack of education and training hinder the competence and competitiveness of informal enterprises, limiting their ability to grow. According to Morris and Pitt (1995:85), informal enterprises in townships generate more sales, create more 
jobs for family and non-family members, have higher growth prospects, and are more sophisticated when the owner, manager and employees have higher formal education levels and skills. The educational level of informal enterprise owners alone also increases their profits (Fourie 2018b:140). Woodward et al. (2011:73) found that business training is more likely to increase the income and sales of micro enterprises due to the variety of business challenges that their enterprises face. Often, informal enterprise owners have good ideas but they do not have the necessary skills to execute the ideas (Barron 2000:1; Brink 1997:364). Kondowe (2013:1) also found that it is unlikely for someone without relevant enterprise management skills to grow an informal enterprise. For informal enterprise owners and managers to increase productivity and income, their enterprise management skills have to be improved (ILO 2009:36).

\section{Gender}

Female informal enterprise owners face more constraints than men as they are more likely to experience 'sociocultural constraints' such as crime and gender stereotyping and discrimination (Co \& Mitchell 2006:350). Berry's (2009:1) study on challenges and coping strategies for informal female-owned street enterprises found that the lack of trading space is a major growth constraint. These challenges may make it difficult for them to develop professional relationships and enterprise networks with other shop owners or suppliers (Department of Trade and Industry 2008:10). Therefore, their male counterparts usually have higher income, sales and profits and are more successful in their enterprise ventures (Hassan 2013:13).

\section{Enterprise and manager characteristics}

The enterprise and manager characteristics include the gender, age, level of education and other qualifications or training of the owner or manager (person in charge of the enterprise), whose idea it was to start the enterprise, the age of the enterprise, the reason for starting the business, whether the business sells a good or service or both and the location of the business.

According to Chandra and Rajaratnam (2001:17), the age of informal enterprises is an indicator of the experience of the informal enterprise's owners in the informal economy and the enterprise's chance of survival. There are mixed findings on whether skilled entrepreneurs run informal enterprises. Advocates of the legalist theory state that entrepreneurs resort to informal enterprises because of the high cost associated with the formal economy (Chen 2012:1). Another view is that informal enterprises are characterised as small, inefficient and usually run by poorly educated entrepreneurs (Rothenberga et al. 2015:5-6).

The theoretical conceptual framework and empirical results on informal enterprises in South Africa provide evidence that informal enterprises are affected by internal and external constraints. The growth constraining factors identified in the literature are used to analyse the factors that constrain the growth of informal enterprises in Diepsloot, Johannesburg. The growth of an enterprise can be measured by an increase in its turnover, revenue, employee numbers, sales or the movement of the enterprise into bigger trading premises (Bridge, O'Neill \& Cromie 1998; Hadebe 2010:15). This article analyses the growth constraints of informal enterprises in Diepsloot in terms of the increase in the number of employees employed by the informal enterprises. This article will provide policymakers with the knowledge to design specific policies for creating an appropriate environment within which these enterprises can grow and sustain themselves.

\section{Materials and methods}

This section discusses the demographic information, research population, sampling strategy, research instrument, design, data collection procedures and data analysis.

Diepsloot in Johannesburg was chosen for this study because it has a fast-growing population and hosts many informal enterprises (ed. Mahajan 2014:150) that are concentrated and conveniently located on the periphery of the township. A previous study in Diepsloot by Hassan (2013:15) indicated that the informal enterprises cluster in areas with a more extensive customer base and a variety of enterprises. Diepsloot harbours a rising class of 'active entrepreneurs' who run profitable, growth-oriented enterprises. Many of these informal enterprises are employment-generating businesses, and have managed to expand (Hassan 2013:17). These characteristics make Diepsloot an ideal township for a follow-up study to investigate growth constraints.

Primary data were collected from 300 of an estimated 1110 South African owned informal enterprises in Diepsloot. A sample size of around 286 enterprises was required to ensure validity of the study and to get results that represent the target population as precisely as possible (Creative Research Systems 2016:1). A convenience sampling technique was used to collect information from these enterprises. The reason for using this non-parametric sampling technique is that informal enterprises in Diepsloot are located close to each other, making it easier for field workers to collect data from many different types of informal enterprises.

A quantitative research approach was followed, and primary data were collected from the persons in charge of the informal enterprises (hereafter referred to as managers), using a structured questionnaire with closed and open-ended questions. A pilot study was conducted to test the questionnaire and to observe the location of the informal enterprises. Owners of four informal enterprises were interviewed in the pilot study and the questionnaires of these informal enterprises were included in the final data set as the questionnaire did not need any changes. During the pilot study, the need to appoint multilingual fieldworkers who could translate the questionnaire to participants with linguistic barriers was identified.

Information was gathered about the owners or persons in charge of the informal enterprises, enterprise characteristics, 
their perceived internal and external growth constraints and their recommendations regarding assistance required to grow their enterprises.

Data were collected in August 2017. The fieldworkers were trained before conducting the interviews to improve the validity and accuracy of the information gathered. All fieldworkers could translate the questionnaire. All ethical principles were adhered to throughout the study, and ethical clearance was obtained for the research.

\section{Data analysis}

The data collected were captured in Excel and analysed in Excel and STATA. The data analysis techniques include a descriptive analysis, matrix analysis and logistic regression models to provide for the different facets of information collected. In the first stage, a descriptive analysis is conducted to determine the profile of the ownership and management of informal enterprises. Frequencies, means, medians and correlations were used in the descriptive analysis. Secondly, a matrix analysis assesses the extent to which the owner or manager perceives some predetermined constraints as minor, moderate or major constraints for their enterprise's growth. In the third stage, three logit regressions were applied. In all three logit models, the enterprise and manager characteristics were used as generic variables. In the first model, only the enterprise and manager characteristics were used. In the second model, only the internal constraints were added to the first model and in the third model, only the external constraints as perceived by the owner or manager were added to the initial model.

The growth of informal enterprises was measured according to the growth in the number of employees. The managers were asked whether the number of employees in the enterprise increased substantially, increased, stayed constant, decreased or decreased substantially. A binary logit model with a dummy variable was used with the value 1 if the number of employees increased and a value of 0 if the number of employees did not increase (decreased or stayed constant).

The logit model seems to be an appropriate model to use as Hassan (2013:20) adopted a similar model to examine constraints that hinder the growth of SMEs in Zanzibar. Adam (2014:133) applied a logit model to investigate constraints and growth potentials of MSEs in Mekelle City, Ethiopia, and Alemayehu and Gecho (2016) adopted it in their study to analyse the determinants of MSE growth in several regions in Ethiopia.

\section{Model specification}

The equation for the logistic regression model is:

$Z i=\beta 0+\beta 1 X 1+\beta 2 X 2+\beta 3 X 3+\beta 4 X 4+\ldots+\beta n X n+U i$

The dependent variable $Z i$ is the probability of the informal enterprise growing in terms of the number of employees. The independent variables include the enterprise and manager characteristics and perceived internal and external constraints.

$X$ is an explanatory variable that determines the informal enterprise growth or lack thereof. $\beta 0$ is the constant term and $\beta 1-\beta n$ are coefficients to be estimated. Table 1 lists the variables used, the measurement units and variable types.

\section{Ethical consideration}

All ethical principles were adhered to throughout the study, and ethical clearance was obtained for the research on 24 July 2017. The ethical clearance number is FEFSREC2017080801.

TABLE 1: Variables and measurement types.

\begin{tabular}{|c|c|}
\hline Dependent variable & $\begin{array}{l}\text { Growth (in employment) } 1 \text { = grew, } \\
0=\text { did not grow }\end{array}$ \\
\hline Gender (manager) & $1=$ male, $0=$ female \\
\hline Age (manager) & Age in years \\
\hline Level of education (manager) & Grades completed (1-12) (manager) \\
\hline Qualification (manager) & $\begin{array}{l}0=\text { no other qualification, } 1=\text { has other } \\
\text { qualification }\end{array}$ \\
\hline Training (manager) & $\begin{array}{l}0=\text { no other training, } 1=\text { has other } \\
\text { training }\end{array}$ \\
\hline Idea (to start enterprise) & $\begin{array}{l}1=\text { owner's idea, } 2 \text { = manager or senior } \\
\text { staff member's idea, } 3=\text { partner's idea, } \\
4=\text { other's idea }\end{array}$ \\
\hline Enterprise age & number of months in business \\
\hline Motivation (to start enterprise) & $\begin{array}{l}1=\text { inherited } 2=\text { unemployment, } 3=\text { low } \\
\text { income, } 4=\text { retrenchment, } 5=\text { market } \\
\text { opportunities } 6=\text { freedom of } \\
\text { self-employment, } 7=\text { entrepreneurship, } \\
8=\text { other }\end{array}$ \\
\hline Product or service & $0=$ service, $1=$ product, $2=$ both \\
\hline Location (of enterprise) & $\begin{array}{l}1=\text { home-based, } 2=\text { on sidewalks, } \\
3=\text { stands, } 4=\text { business commercial } \\
\text { area, } 5=\text { other }\end{array}$ \\
\hline Own money & $0=$ no constraint, $1=a$ constraint \\
\hline Inadequate education (manager) & $0=$ no constraint, $1=a$ constraint \\
\hline Inadequate education (employees) & $0=$ no constraint, $1=$ a constraint \\
\hline Lack of managerial skills (manager) & $0=$ no constraint, $1=$ a constraint \\
\hline Lack of entrepreneurial skills (manager) & $0=$ no constraint, $1=a$ constraint \\
\hline Lack of entrepreneurial skills (employees) & $0=$ no constraint, $1=a$ constraint \\
\hline Employee cost & $0=$ no constraint, $1=a$ constraint \\
\hline Theft by employees & $0=$ no constraint, $1=$ a constraint \\
\hline Customer credit & $0=$ no constraint, $1=$ a constraint \\
\hline Customer default & $0=$ no constraint, $1=$ a constraint \\
\hline Government funding & $0=$ no constraint, $1=a$ constraint \\
\hline Funding agency & $0=$ no constraint, $1=$ a constraint \\
\hline Commercial bank funds & $0=$ no constraint, $1=$ a constraint \\
\hline Micro-lender funds & $0=$ no constraint, $1=$ a constraint \\
\hline Infrastructure & $0=$ no constraint, $1=$ a constraint \\
\hline Water supply & $0=$ no constraint, $1=$ a constraint \\
\hline Land ownership & $0=$ no constraint, $1=$ a constraint \\
\hline Roads and streetlights & $0=$ no constraint, $1=$ a constraint \\
\hline Sewerage facility & $0=$ no constraint, $1=a$ constraint \\
\hline Electricity & $0=$ no constraint, $1=$ a constraint \\
\hline Competition (foreigners) & $0=$ no constraint, $1=$ a constraint \\
\hline Competition (shopping malls) & $0=$ no constraint, $1=\mathrm{a}$ constraint \\
\hline Price of raw materials & $0=$ no constraint, $1=a$ constraint \\
\hline Transportation costs & $0=$ no constraint, $1=\mathrm{a}$ constraint \\
\hline Cost of employee strikes & $0=$ no constraint, $1=$ a constraint \\
\hline Cost of technology & $0=$ no constraint, $1=$ a constraint \\
\hline Theft by customers & $0=$ no constraint, $1=a$ constraint \\
\hline Theft by criminals & $0=$ no constraint, $1=$ a constraint \\
\hline Intimidation from customers & $0=$ no constraint, $1=$ a constraint \\
\hline Non-financial support & $0=$ no constraint, $1=$ a constraint \\
\hline Lack of security & $0=$ no constraint, $1=a$ constraint \\
\hline
\end{tabular}




\section{Results}

\section{Demographic profile of owners, managers and informal enterprises}

As seen in Table 2, almost two-thirds (61.3\%) of the 349 enterprise owners are male. Half (49.9\%) of the enterprise owners are youths according to the broad definition of a youth (15-34 years). The dominating ethnical group is African (97.3\%) with $2.6 \%$ Indian participants.

The managers of the informal enterprises are, in most cases $(77 \%)$, the owners themselves with only $23 \%$ non-owner managers. The youngest manager is 17 , whilst the oldest manager is 75 , with an average age of 36 . The majority (77.3\%) of the managers have not completed their secondary education, and $6 \%$ have no school education. The mean education level of the managers is Grade 9, and the median is Grade 10, implying that the grades are 'skewed to the left'. Only $18.3 \%$ and $14 \%$ of managers have other qualifications and training.

Only 22\% enterprises had more employees than when they started. Approximately $6.6 \%$ had fewer employees, and the majority (71.3\%) of enterprises' number of employees did not change. Table 3 shows the total number of employees in the informal enterprises at start-up and their current number of employees. The permanent full-time employees decreased slightly from $88 \%$ to $83 \%$. Additionally, the number of casuals, permanent and temporary part-time and temporary full-time employees has increased slightly. Informal enterprises in Diepsloot, therefore, provide secure employment opportunities to people as they predominantly employ permanent full-time employees.

\section{Profile of the enterprises}

The age of the informal enterprise, measured from the month and year it started operating until the month-end of August 2017, shows a minimum enterprise age of 1 month and a maximum of 44 years. The result implies that this enterprise was in that area before the establishment of Diepsloot in 1995. The mean and median age of the informal enterprises is 83 months and 63 months (Table 2). According to Fourie (2018b:132), there is a positive relationship between the age of a firm and profits, and a negative relationship between age and employment growth.
The majority (70.3\%) of informal enterprise owners in Diepsloot sourced their start-up capital from their savings, $18.3 \%$ obtained it from family and friends, $2.7 \%$ from micro-lenders, $0.7 \%$ from bank loans and $8 \%$ from other sources, as indicated in Table 4.

The majority $(85.7 \%)$ of the respondents indicated that the decision to start the enterprise was that of the owners of the

TABLE 3: Change in the type and number of employees since start-up, Diepsloot $(n=300)$.

\begin{tabular}{lcccccc}
\hline Employment type & \multicolumn{2}{c}{ At start of enterprise } & & \multicolumn{2}{c}{ Current } \\
\cline { 2 - 3 } \cline { 5 - 6 } & $\boldsymbol{N}$ & $\mathbf{\%}$ & & $\boldsymbol{N}$ & $\mathbf{\%}$ \\
\hline Permanent full-time & 230 & 88 & & 218 & 83 \\
Permanent part-time & 9 & 3 & & 17 & 7 \\
Temporary full-time & 5 & 2 & & 8 & 3 \\
Temporary part-time & 2 & 1 & & 3 & 1 \\
Casual & 15 & 6 & & 17 & 7 \\
Contract & 0 & 0 & & 0 & 0 \\
\hline Total & $\mathbf{2 6 1}$ & $\mathbf{1 0 0}$ & & $\mathbf{2 6 3}$ & $\mathbf{1 0 0}$ \\
\hline
\end{tabular}

Source: Statistics South Africa, 2017, Quarterly labour force survey: Quarter 3: 2017 (July to September), Statistics South Africa, Pretoria, viewed 10 May 2018, from http://www.statssa. gov.za/

TABLE 4: Enterprise characteristics $(n=300)$.

\begin{tabular}{|c|c|}
\hline Characteristics & Results \\
\hline $\begin{array}{l}\text { Source of start-up } \\
\text { capital }\end{array}$ & $\begin{array}{l}\text { Own savings } 70.3 \% \\
\text { Family and friends } 18.3 \% \\
\text { Micro-lenders } 2.7 \% \\
\text { Banks loans } 0.7 \% \\
\text { Other } 8 \%\end{array}$ \\
\hline $\begin{array}{l}\text { Decision to start } \\
\text { the enterprise }\end{array}$ & $\begin{array}{l}\text { Owners of the enterprise } 85.7 \% \\
\text { Managers } 6.3 \% \\
\text { Partners } 6 \% \\
\text { Family members and friends } 2 \%\end{array}$ \\
\hline $\begin{array}{l}\text { Motivation for } \\
\text { starting the } \\
\text { enterprise }\end{array}$ & $\begin{array}{l}\text { Owner had no alternative employment } 56 \% \\
\text { To subsidise or supplement owners' household income } 13 \% \\
\text { Innovativeness of the owners } 7 \% \\
\text { Owners retrenched or dismissed from previous job } 6 \% \\
\text { Inherited their enterprises } 5 \% \\
\text { Owners prefer self-employment } 5 \% \\
\text { Other reasons } 8 \%\end{array}$ \\
\hline $\begin{array}{l}\text { Premises of } \\
\text { operations }\end{array}$ & $\begin{array}{l}\text { Sidewalk } 44 \% \\
\text { Stands } 32.3 \\
\text { From their homes } 20.3 \% \\
\text { Taxi rank stands, commercial business areas and stands } 3.4 \%\end{array}$ \\
\hline Enterprise business & $\begin{array}{l}\text { Sell products } 65.7 \% \\
\text { Sell services } 20.3 \% \\
\text { Sell both products and services } 14 \%\end{array}$ \\
\hline
\end{tabular}

Source: Statistics South Africa, 2017, Quarterly labour force survey: Quarter 3: 2017 (July to September), Statistics South Africa, Pretoria, viewed 10 May 2018, from http://www.statssa. gov.za/

TABLE 2: Demographic profile of owners and managers.

\begin{tabular}{|c|c|c|c|c|c|c|c|c|c|c|}
\hline \multirow[t]{3}{*}{ Demographics } & \multicolumn{10}{|c|}{ Profile of owners $(n=349)$ and managers $(n=300)$} \\
\hline & \multirow[t]{2}{*}{ Total } & \multicolumn{2}{|c|}{ Male } & \multicolumn{2}{|c|}{ Female } & \multirow[t]{2}{*}{ Minimum } & \multirow[t]{2}{*}{ Maximum } & \multirow[t]{2}{*}{ Mean } & \multirow[t]{2}{*}{ Median } & \multirow[t]{2}{*}{ Standard deviation } \\
\hline & & $N$ & $\%$ & $N$ & $\%$ & & & & & \\
\hline Gender (owners) & 349 & 214 & 61.0 & 135 & 39.0 & - & - & - & - & - \\
\hline Gender (managers) & 300 & 182 & 60.7 & 118 & 39.3 & - & - & - & - & - \\
\hline Age (Owners) & - & - & - & - & - & 17 & 78 & 39.0 & 36 & 11.1100 \\
\hline Age (Managers) & - & - & - & - & - & 17 & 75 & 36.0 & 34 & 10.6000 \\
\hline Level of education (managers) & 300 & - & - & - & - & 0 & 12 & 9.0 & 10 & 3.4900 \\
\hline Other qualification (managers) & 55 & 37 & 12.0 & 18 & 6.0 & - & - & - & - & - \\
\hline Other training (managers) & 43 & 29 & 9.7 & 14 & 4.7 & - & - & - & - & - \\
\hline Enterprise months in operation & - & - & - & - & - & 1 & 535 & 83.1 & 63 & 81.7650 \\
\hline
\end{tabular}

Source: Statistics South Africa, 2017, Quarterly labour force survey: Quarter 3: 2017 (July to September), Statistics South Africa, Pretoria, viewed 10 May 2018, from http://www.statssa.gov.za/ 
enterprise while only $6.3 \%$ of the enterprises were started based on the ideas of the managers.

Approximately $6 \%$ were initiated by partners, and in $2 \%$ of the cases, the idea came from family members and friends. More than half $(56 \%)$ of the enterprises were started because the owner had no alternative employment while $13 \%$ were started to subsidise and supplement the owners' low household income. Only 7\% of the enterprises were started because of the innovativeness of the owners, $6 \%$ were retrenched or dismissed from their previous jobs, $5 \%$ inherited their enterprises, $5 \%$ started the enterprise because they prefer self-employment, and $8 \%$ started because of other reasons.

Of all the informal enterprises, $65.7 \%$ sell products, $20.3 \%$ sell services, and $14 \%$ sell both products and services. Informal enterprises that sold both products and services were for example hair salons (that sell beauty products and braid hair), car enterprises (that wash cars, fix cars and sell car parts) and internet or phone cafes (that provide internet services, sell airtime and other products).

Most informal enterprises (44\%) operate on the street sidewalk, requiring no rental payments, with many people passing by on their way home from work. Another 20.3\% operate from their homes, also not requiring paying rent to operate. Those operating on stands at taxi ranks near commuters, or on stands in commercial business areas where the rent had to be paid, made up $32.3 \%$ and $3.4 \%$ respectively.

\section{Growth constraining factors}

To identify the factors that constrain the growth of the informal enterprises, the manager had to indicate, on a list of factors provided to them, which factors constrain the growth of their enterprises. They had to rate the extent to which each factor constrained the enterprise's growth. A rating of 1 indicates a 'minor constraint', 2 a 'moderate constraint', and 3 a 'major constraint'.

Table 5 displays the matrix of enterprise growth constraints as perceived by informal enterprise managers.

More than $70 \%$ of managers see a lack of proper infrastructure, price of raw materials, merchandise and inputs, and competition as growth constraints. More than $50 \%$ ranked these as a significant constraint. More than half of the enterprises ranked cost of transportation, lack of savings,

TABLE 5: Matrix of internal enterprise growth constraints $(n=300)$

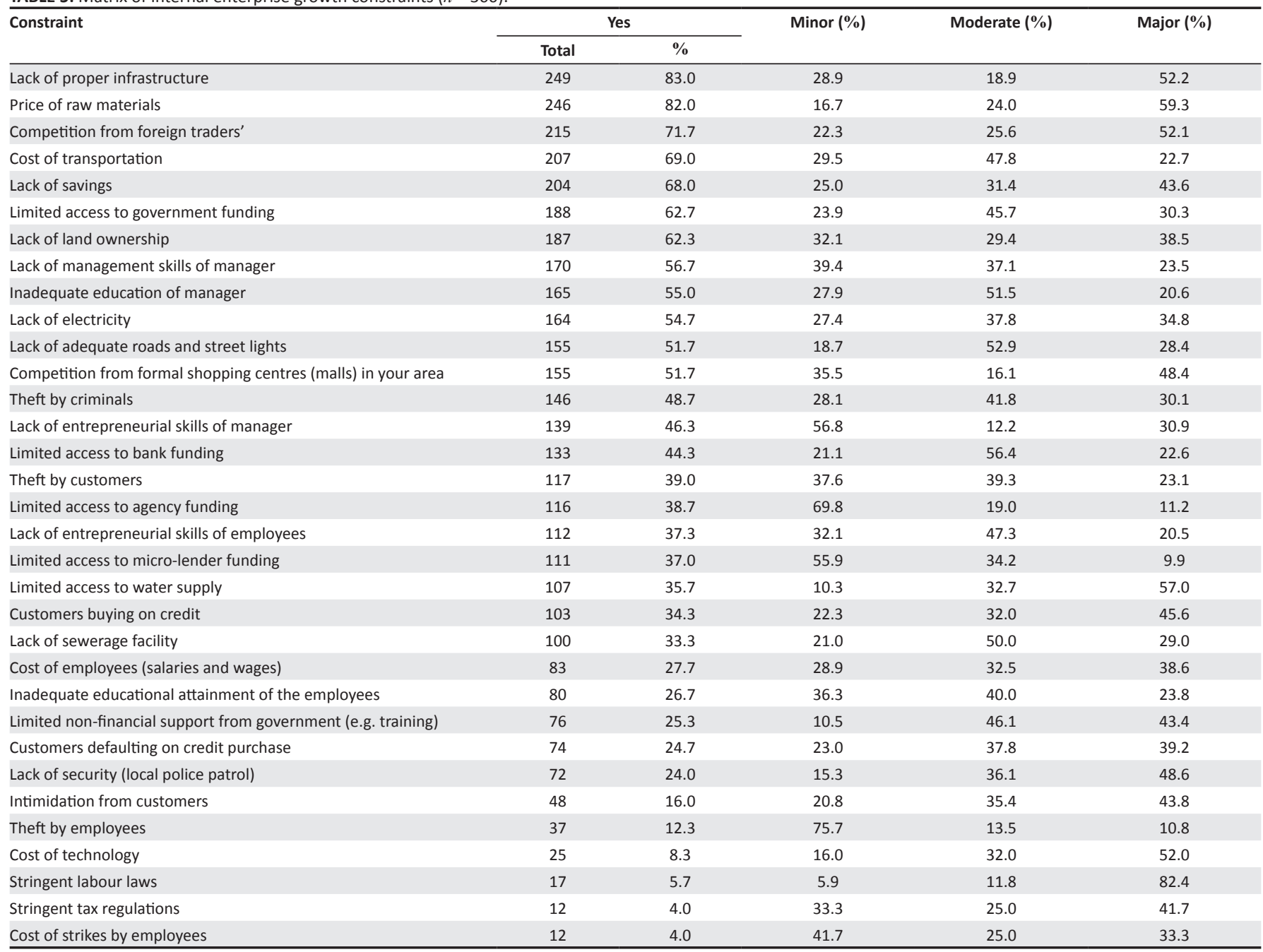

Source: Statistics South Africa, 2017, Quarterly labour force survey: Quarter 3: 2017 (July to September), Statistics South Africa, Pretoria, viewed 10 May 2018, from http://www.statssa.gov.za/ 
limited access to government funding, lack of land ownership, lack of business management skills and inadequate educational attainment level of managers, lack of electricity, inadequate roads and streetlights, competition from formal shopping malls in the area, and competition from foreign traders as growth constraints.

The relationship between the enterprise's growth and the enterprise and manager characteristics, internal and external constraints, and the significance thereof, are analysed with logistic regression models. The dependent variable is enterprise growth, measured by whether or not there was an increase in the number of employees since the enterprises started. The internal and external constraints used are those perceived by the managers as a constraint to the growth of the enterprise. The first model (Model I) only controls for the enterprise and manager characteristics. The second model (Model II) controls for the enterprise and manager characteristics and the internal growth constraints, and the third model (Model III) controls for the enterprise and manager characteristics and the external growth constraints.

\section{Results of the enterprise and manager characteristics}

The results from the logistic regression controlling only for enterprise and manager characteristics showed that informal enterprises with male managers were more likely to grow than those with female managers. The odds ratio of 1.846471 is statistically significant at a $10 \%$ level. Controlling for enterprise and manager characteristics and internal growth constraints (Model II), enterprises with male managers had a

TABLE 6: Relationship between enterprise growth and manager and enterprise characteristics and internal constraints: Logit regression results.

\begin{tabular}{|c|c|c|c|c|c|c|}
\hline \multirow[t]{2}{*}{ Increase in employment } & \multicolumn{3}{|c|}{ Model I } & \multicolumn{3}{|c|}{ Model II } \\
\hline & Odds Ratio & SD & $z$-value & Odds Ratio & SD & $z$-value \\
\hline Gender (manager) & $1.846471 *$ & 0.6348035 & 1.78 & $1.973261 *$ & 0.6967669 & 1.92 \\
\hline Age (manager) & 0.9994343 & 0.0164126 & -0.03 & 1.002635 & 0.0171627 & 0.15 \\
\hline Level of education (manager) & 1.058241 & 0.0557303 & 1.07 & 1.06441 & 0.0579089 & 1.15 \\
\hline Qualification (manager) & 1.521131 & 0.6612479 & 0.96 & 1.592572 & 0.7224224 & 1.03 \\
\hline Training (manager) & $3.307993 * * *$ & 1.488966 & 2.66 & $3.280585 * *$ & 1.554367 & 2.51 \\
\hline \multicolumn{7}{|l|}{ Idea ( $R=$ Owner $)$} \\
\hline Manager & 1.647297 & 1.071898 & 0.77 & 1.736004 & 1.168521 & 0.82 \\
\hline Partner & $3.362227^{* *}$ & 2.057768 & 1.98 & $3.67682 * *$ & 2.325154 & 2.06 \\
\hline Other & 2.632613 & 2.765504 & 0.92 & 3.419094 & 3.568443 & 1.18 \\
\hline Enterprise age & $1.006392 * * *$ & 0.0019774 & 3.24 & $1.006481 * * *$ & 0.0020577 & 3.16 \\
\hline \multicolumn{7}{|l|}{ Motivation ( $R=$ inherited) } \\
\hline Unemployment & 0.6828998 & 0.4691707 & -0.56 & 0.6388248 & 0.4545038 & -0.63 \\
\hline Low income & 0.3851101 & 0.3176417 & -1.16 & 0.3106338 & 0.2637966 & -1.38 \\
\hline Retrenchment & 0.4359145 & 0.3942021 & -0.92 & 0.3759983 & 0.3544825 & -1.04 \\
\hline Market opportunities & 2.161686 & 2.022413 & 0.82 & 1.927532 & 1.90668 & 0.66 \\
\hline Freedom of self-employment & $0.0838022^{*}$ & 0.1122163 & -1.85 & $0.0425275 * *$ & 0.0604781 & -2.22 \\
\hline Entrepreneurship & 0.5927038 & 0.5008355 & -0.62 & 0.5116059 & 0.4483613 & -0.76 \\
\hline Other & 2.274797 & 2.325096 & 0.80 & 1.882365 & 1.959191 & 0.61 \\
\hline \multicolumn{7}{|l|}{ Product/service ( $R=$ products) } \\
\hline Services & $2.232667 * *$ & 0.875425 & 2.05 & $2.065829 *$ & 0.8486457 & 1.77 \\
\hline Both & 1.4178 & 0.6456428 & 0.77 & 1.707317 & 0.8274442 & 1.10 \\
\hline \multicolumn{7}{|l|}{ Location ( $R=$ house based) } \\
\hline Next to street & 0.7228017 & 0.3215866 & -0.73 & 0.7215666 & 0.3353143 & -0.70 \\
\hline Stand & 0.6578312 & 0.2854704 & -0.97 & 0.7461086 & 0.3375244 & -0.65 \\
\hline Business commercial area & 0.4921691 & 0.6129987 & -0.57 & 0.3729977 & 0.4768715 & -0.77 \\
\hline Other & 0.3957889 & 0.5173096 & -0.71 & 0.4080833 & 0.565645 & -0.65 \\
\hline Own money & - & - & - & 0.7912364 & 0.2774225 & -0.67 \\
\hline Inadequate education (manager) & - & - & - & 0.8432792 & 0.4872534 & -0.30 \\
\hline Inadequate education (employees) & - & - & - & 1.388177 & 0.7145566 & 0.64 \\
\hline Lack of management skills (manager) & - & - & - & 1.796392 & 0.9051987 & 1.16 \\
\hline Lack of entrepreneurial skills (manager) & - & - & - & 1.045385 & 0.5853006 & 0.08 \\
\hline Lack of entrepreneurial skills (employees) & - & - & - & 0.7097528 & 0.2817959 & -0.86 \\
\hline Employee cost & - & - & - & 1.388567 & 0.6602302 & 0.69 \\
\hline Theft by employees & - & - & - & 1.19844 & 0.6585109 & 0.33 \\
\hline Customer credit & - & - & - & 0.629712 & 0.3448667 & -0.84 \\
\hline Customer default & - & - & - & 0.9834058 & 0.5733387 & -0.03 \\
\hline _cons & 0.066132 & 0.0695681 & -2.58 & 0.0506146 & 0.0567384 & -2.66 \\
\hline Observations & - & - & 300 & - & - & 300 \\
\hline Adjusted $R$ squared & - & - & 0.1565 & - & - & 0.1778 \\
\hline Prob > chi2 & - & - & 0.0007 & - & - & 0.0051 \\
\hline
\end{tabular}

Source: Statistics South Africa, 2017, Quarterly labour force survey: Quarter 3: 2017 (July to September), Statistics South Africa, Pretoria, viewed 10 May 2018, from http://www.statssa.gov.za/ $*, p \leq 0.05 ; * *, p \leq 0.01 ; * *, p \leq 0.001$. 
TABLE 7: Relationship between enterprise growth, manager and enterprise characteristics and external constraints: Logit regression results.

\begin{tabular}{|c|c|c|c|}
\hline \multirow[t]{2}{*}{ Increase in employment } & \multicolumn{3}{|c|}{ Model III } \\
\hline & Odds Ratio & SD & $z$-value \\
\hline Gender & 1.65567 & 0.6397812 & 1.30 \\
\hline Age & 1.014507 & 0.019552 & 0.75 \\
\hline Level of education & $1.138894 *$ & 0.0770641 & 1.92 \\
\hline Qualification & 1.263647 & 0.6733209 & 0.44 \\
\hline Training & $4.942432 * * *$ & 2.696756 & 2.93 \\
\hline \multicolumn{4}{|l|}{ Idea (Owner) } \\
\hline Manager or senior staff & 1.969457 & 1.567618 & 0.85 \\
\hline Partners & $3.340543 *$ & 2.258595 & 1.78 \\
\hline Other & 3.797925 & 4.082187 & 1.24 \\
\hline Enterprise age (months) & $1.008046 * * *$ & 0.0023185 & 3.48 \\
\hline \multicolumn{4}{|l|}{ Motivation ( $R=$ Inherited) } \\
\hline Unemployment & 0.6467966 & 0.523425 & -0.54 \\
\hline Low income & 0.273919 & 0.2639371 & -1.34 \\
\hline Retrenchment & 0.1875216 & 0.2091694 & -1.50 \\
\hline Market opportunities & 1.842241 & 2.099544 & 0.54 \\
\hline Freedom of self-employment & $0.0486812 * *$ & 0.071541 & -2.06 \\
\hline Entrepreneurship & 0.7149928 & 0.7156045 & -0.34 \\
\hline Other & 3.796783 & 4.412658 & 1.15 \\
\hline \multicolumn{4}{|l|}{ Product/service $(\boldsymbol{R}=$ product $)$} \\
\hline Services & $2.863277 * *$ & 1.289218 & 2.34 \\
\hline Both & 1.428116 & 0.7836032 & 0.65 \\
\hline \multicolumn{4}{|l|}{ Location $(R=$ House based $)$} \\
\hline On the street & 0.6316364 & 0.3288411 & -0.88 \\
\hline Stand & 0.5973478 & 0.2968185 & -1.04 \\
\hline Business commercial area & 1.464776 & 1.880949 & 0.30 \\
\hline Other & 0.2165978 & 0.333119 & -0.99 \\
\hline Government funding & $3.864616 * *$ & 2.562328 & 2.04 \\
\hline Funding agency & $0.052859 * * *$ & 0.0574855 & -2.70 \\
\hline Commercial bank funds & 0.3707268 & 0.2784558 & -1.32 \\
\hline Micro lender funds & $18.73403 * * *$ & 19.45144 & 2.82 \\
\hline Infrastructure & 2.067268 & 1.011272 & 1.48 \\
\hline Water supply & 1.601059 & 0.8690958 & 0.87 \\
\hline Landownership & 0.4009038 & 0.2290397 & -1.60 \\
\hline Roads and streetlights & 0.761923 & 0.379906 & -0.55 \\
\hline Sewerage facility & $0.2718777 * *$ & 0.1510264 & -2.34 \\
\hline Electricity & 1.293698 & 0.7205313 & 0.46 \\
\hline Competition (foreigners) & 1.806914 & 0.8515164 & 1.26 \\
\hline Competition (shopping malls) & $4.691261 * * *$ & 2.4759 & 2.93 \\
\hline Price of raw materials & 1.37089 & 0.5579614 & 0.78 \\
\hline Transportation costs & 0.4891801 & 0.2639649 & -1.33 \\
\hline Cost of employee strikes & 1.452921 & 1.584843 & 0.34 \\
\hline Cost of technology & 1.73238 & 1.594688 & 0.60 \\
\hline Theft by customers & 0.6290388 & 0.3557491 & -0.82 \\
\hline Theft by criminals & 1.017329 & 0.5891215 & 0.03 \\
\hline Intimidation from customers & 0.6791558 & 0.5562921 & -0.47 \\
\hline Non-financial support & .7697399 & 0.5878842 & -0.34 \\
\hline Lack of security & 2.500947 & 1.936944 & 1.18 \\
\hline _cons & 0.01222 & 0.0171295 & -3.14 \\
\hline Observations & - & - & 300 \\
\hline Adjusted R-squared & - & - & 0.2771 \\
\hline Prob > chi2 & - & - & 0.0001 \\
\hline
\end{tabular}

Source: Statistics South Africa, 2017, Quarterly labour force survey: Quarter 3: 2017 (July to September), Statistics South Africa, Pretoria, viewed 10 May 2018, from http://www.statssa. gov.za/

$*, p \leq 0.05 ; * *, p \leq 0.01 ; * * *, p \leq 0.001$

$97 \%$ higher likelihood to have an enterprise that grows than those with females at a $10 \%$ statistical significance level.

Controlling for enterprise and manager characteristics and external constraints (Model III), the odds ratio for gender
(1.655567) showed similar results but was not statistically significant. The age of the managers does not seem to predict whether an informal enterprise is more or less likely to grow.

Higher levels of education and additional qualifications of managers seem to increase the likelihood of enterprise growth, but the results are not statistically significant. However, informal enterprises whose managers have additional training are between three (in Model I and Model II) and five times (in Model III) more likely to grow than enterprises with managers without training. Additional training is statistically significant at a 1\% level in Model I and Model III, and a 5\% level in Model II. Chebelyon-Dalizu et al. (2010:13) agree that a lack of enterprise management skills is one of the significant challenges that many informal enterprise owners face.

When the idea of starting the enterprise came from someone else besides the owner, the chances of an enterprise growing is higher. When the start-up was initiated by an idea from a partner, the enterprise was 3.4, 3.7 and 3.3 times more likely to grow in Model I, Model II and Model III. This finding is statistically significant at a 5\% level in the first two models, and 10\% level in Model III.

Every additional month that the enterprise operates seems to increase the enterprise's likelihood of growth. These results are statistically significant at a $1 \%$ level in all models.

The different reasons for starting the enterprise revealed no statistically significant results except in the case where the enterprise was started to have freedom of self-employment. Enterprises with this motive are more likely not to grow, and the result is statistically significant at a $5 \%$ level in all models. Enterprises that were started because of market opportunities (entrepreneurial motive) were the only motive that makes an enterprise more likely to grow in all three models with odds ratios of 2.16, 1.93 and 1.84, although the results are not statistically significant. In cases where the motive for starting the enterprise was unemployment, low income, retrenchment, freedom of self-employment and entrepreneurship, the likelihood of no enterprise growth is higher.

Enterprises that sell services and both products and services are more likely to grow than those who only sell products. Enterprises selling services have the highest likelihood of growth with odds ratios of 2.23, and 2.07 in Model I and Model II and 2.86 in Model III. These results are statistically significant in all models. The location from which the enterprise operates did not yield any significant results. These results confirm the results of a national study by Fourie (2018b:133) over the period 2009-2013 that the location from which the informal enterprises operate was not found to be statistically significant in the propensity to increase employment.

\section{Results of the internal constraints}

Enterprises that perceived a lack of their own money, inadequate education of managers, lack of entrepreneurial 
skills of employees, credit purchases by customers and customers defaulting on credit as a constraint are less likely to experience enterprise growth. Enterprises that perceived inadequate education of employees, lack of business skills and entrepreneurial skills of the manager, employee cost and theft by employees as a constraint are more likely to experience enterprise growth, but the predictions are weak.

\section{Results of external constraints}

Enterprises who perceived a lack of agency funding, commercial bank funding, land ownership, proper roads and street lights, and sewerage facilities as growth constraints are more likely not to grow with odds ratios of $052859,0.3707268$, $0.4009038,0.761923$ and 0.2718777 . The result for lack of agency funding is statistically significant at a $1 \%$ level, and the results for lack of sewerage facilities are statistically significant at a $5 \%$ level.

Enterprises who perceived high transport costs and a lack of non-financial support from the government as a constraint to their enterprises' growth are also more likely not to grow with odds ratios of 0.4891801 and 0.7697399 , but these results are not statistically significant. Although the results for high transport costs as a growth constraint were not statistically significant, Hassan (2013:18) points out that it is indeed a constraint faced by informal enterprises in Diepsloot that should be addressed. Chebelyon-Dalizu et al. (2010:14) confirm that high transportation costs are a growth constraint for informal enterprises.

The managers of enterprises that are more likely to grow perceived a lack of micro-lender funding, proper infrastructure, water and electricity supply, competition from foreign traders and shopping malls, price of raw materials, cost of employee strikes, cost of technology, theft by criminals and lack of security as growth constraints. The odds ratio of the lack of micro-lender funding as a growth constraint is 18.73403 and statistically significant at a $1 \%$ level. The odds where managers perceive a lack of proper infrastructure, water and electricity supply as constraints to the growth of their enterprises are $2.067268,1.601059$ and 1.2939698 but are not statistically significant.

Managers who perceive competition from foreign traders and shopping malls as constraints are also 1.80 and 4.69 times more likely to have an enterprise that grows than those who do not perceive it as a constraint. The results for the competition from shopping malls are statistically significant at a $1 \%$ level.

The odds for the price of raw materials, the cost of technology, criminal theft, lack of security and cost of employee strikes are $1.37089,1.73238,1.017329,2.50097$ and 1.452921. None of these results are statistically significant.

\section{Diagnostic tests}

The Hosmer-Lemeshow goodness of fit test results of 12.76 , 8.70 and 3.12 with probabilities of $0.1203,0.3678$ and 0.9265 imply good model fit and confirm that the models used are correctly specified and fit the data adequately. Collin's multicollinearity test results $(1.12,1.5$ and 1.96) show no multicollinearity concerns.

\section{Discussion}

The enterprise and manager characteristics that yield statistically significant results are gender, additional training of managers, a partner's business idea, age of the informal enterprises, freedom of self-employment, and whether the enterprise sells products, services or both.

Enterprises with male managers (mostly also the owners) are more likely to have an enterprise that grows measured by an increase in the number of employees. This result confirms the finding of Fourie (2018b:138, 140) that male informal enterprise owners are more likely to employ more employees than female informal enterprise owners. There might be several reasons for the lower growth of female-owned or -managed informal enterprises and might include the higher level of sociocultural constraints that women face like crime, gender stereotyping and discrimination as pointed out by Chebelyon-Dalizu et al. $(2010: 11,16)$. Other reasons as cited by Hassan (2013:13) include the fact that female-owned informal enterprises are likely to have less income and lower profits. Women are also less likely to be 'active entrepreneurs', which can be attributed to the fact that they have more family responsibilities. This makes it more difficult for them to develop professional relationships and enterprise networks with other shop owners or suppliers (DTI 2008:10), thus limiting their social capital. Male informal enterprise owners do not face the same challenges and could, therefore, be more successful. Male owners might also be the sole breadwinners which might motivate them more to ensure the success of their enterprises.

Every additional year of education of managers and having other qualifications and training increases the likelihood of enterprise growth. Although the predictions for additional years of education are weak, the predictions for the additional training of managers are statistically significant at a 1\% level (Model I and Model III) and a 5\% level (Model II). A national study by Fourie (2018b:132) also found no significant association between the education of the owners and employee growth. Although Smith and Perks (2006:1, 23) advocate that education, management, and entrepreneurial skills are likely determinants of an enterprise's growth, they warn that not all training methods and qualifications are suitable to develop the entrepreneurial skills of informal enterprise owners and managers. The skills levels of owners and managers of informal enterprises are factors that need further research.

Enterprises that started because of a partner's idea are more likely to grow. This might inspire owners to make sure that the partners' idea is working and that the enterprise survives. It might also be that the partner supports the owner to ensure enterprise growth. 
The result that every additional month of enterprise operation slightly increases the enterprise's likelihood of growth are in contrast with the finding from Fourie (2018b:132) in 2013, which found a negative relationship between the age of the enterprise and employment growth. This negative relationship in 2013 might be due to the fact that in that study most informal enterprises (79\%) had been operating for less than 12 months, whilst only $21 \%$ had survived for longer than 12 years (Fourie 2018b:130). It seems that we can conclude that the longer the enterprise in Diepsloot can survive, the more likely the enterprise will grow. This result also supports the view of Smith and Perks (2006:24) that most informal enterprise owners and managers acquire their skills through learning by doing. The longer the enterprise survives, the more skilful the owner or manager becomes.

None of the internal constraints produce statistically significant results and only explains an additional $2 \%$ of the model. These findings coincide with the findings in the earlier study by the World Bank (Rakabe 2018:304) that internal constraints were not perceived as critical to business growth.

The results further showed that managers of enterprises that were more likely to grow perceived different factors as growth constraints than those enterprises that were less likely to grow. The factors identified as statistically significant growth constraints by enterprises that are more likely not to grow are access to funding either from agency funding sources or commercial bank funding, land ownership, proper roads and streetlights, and sewerage facilities. This finding is in line with evidence from Fatoki (2014:31) who states that inaccessibility and exclusion from external finance is still a growth constraint for informal enterprises.

A lack of sewerage facilities seems to be a significant growth constraint for enterprises that are less likely to grow. Although there are communal mobile toilets in Diepsloot, some of the stands do not have sewerage facilities provided by the municipality and, in some cases, the toilets are not well maintained. The managers indicated that this poses health risks and might prevent potential clients from buying from them.

The results also showed that more and better access to commercial bank funding and agency funding might assist enterprises to grow. These results back the observation by Schoombee (2000:752) and Willemse (2011:8) that there is little contact between formal financial institutions and the informal economy in South Africa because informal enterprises are considered 'high risk' due to their possibility of defaulting on credit and their low returns. Schoombee, however, believes that South Africa's commercial banks can assist informal enterprises by applying suitable banking strategies directed towards informal enterprises.

Factors that constrain the growth of enterprises that are more likely to grow include access to affordable micro-lender and government funding, lack of proper infrastructure such as water and electricity supply. Lack of electricity was also identified by Hassan (2013:18) as a constraint for informal enterprises in Diepsloot in 2012. It further seems that competition from foreign traders and shopping malls are an additional growth constraint.

The price of raw materials, cost of technology, criminal theft, lack of security and cost of employee strikes also constrain the growth of informal enterprises. The lack of micro-lender funding was perceived by the enterprises that are more likely to grow as a growth constraint. Consequently, this might imply that the type of funding currently offered by micro-lenders is not aligned to the funding needs of informal enterprises in Diepsloot. The interest rates are inflated on these types of loans. Most informal enterprises cannot afford them.

The results of this study agree with the results of Rolfe et al. (2011:5) who concluded that informal retail enterprises located near shopping malls lose sales and revenue to the shops in the malls. Rolfe et al. therefore also believe that shopping malls in urban and rural areas exert potentially negative impacts on informal retail enterprises. Ligthelm (2008:372) also asserts that shopping malls pose a challenge to informal enterprises as many potential customers shop at these malls. According to Ligthelm, the decline in the sales of informal enterprises was noticeable six months after the formal shopping malls were established in the townships. This suggests that the establishment of shopping malls has implications for customer satisfaction and loyalty to informal enterprises (Oni \& Fatoki 2013:5).

To counteract the competition from foreign informal traders, the informal enterprise owners and managers can differentiate their products from foreign traders and should improve their networking skills, as Hassan (2013:18) found that foreign informal enterprises are more successful because of their business connections.

A lack of government funding was a constraint for enterprises that are more likely to grow. According to Monkman (2003:23), only a few enterprises have benefited from government funding programmes. Government programmes most often fail because of a lack of awareness, uneven geographical coverage, and weak local government support (Monkman 2003:23). Informal enterprise owners and managers believe that if they had access to government funding programmes, their enterprises would grow. The South African government should create awareness and offer funding opportunities to informal enterprises in townships.

Apart from financial assistance, many informal enterprises also indicated that they require other non-financial support from the government and municipalities like proper infrastructure, water and electricity supply, and sewerage facilities. 


\section{Strengths and limitations}

This study has some limitations that must be considered when interpreting the results. Firstly, the study was limited to only one township, namely Diepsloot in Johannesburg. This suggests that, to some extent, these results might reflect regional (geographical) differences, culture and economic trends. Only the change in the number of employees was used to measure the growth of informal enterprises. The study can be extended to other locations, and the use of other measures for the growth of informal enterprises like the increase in the enterprise's turnover, revenue, sales, or the movement of the enterprise into a bigger trading premise can be applied.

\section{Conclusions and recommendations}

The literature indicates that most informal enterprises exhibit stagnant growth. This article shows that only $22 \%$ of the informal enterprises in Diepsloot show growth in terms of an increase in the number of employees. Despite this, these enterprises play a critical role in the community by creating mostly permanent full-time employment and incomegenerating opportunities. The informal enterprises further contribute to the circulation of income within the Diepsloot community and should, therefore, be recognised and empowered to grow.

Several factors were identified that constrain the growth of informal enterprises. The statistically significant growth constraints faced by informal enterprises in Diepsloot are all external constraints over which the managers usually have no control. These constraints should, however, be managed by the managers which requires specific skills and training. This might explain the highly significant likelihood of an enterprise growing for managers that have other training. This article suggests interactive action learning, role-model learning, simulation and case study scenario learning following Smith and Perks's (2006:24) suggestions. Government, agencies and private institutions can offer this training, but it must take into account that many informal enterprise managers do not have basic education or funding for this training.

Training should also be complemented by improved and affordable access to funding either from agency funding sources or commercial bank funding to ensure that the trained managers can implement their skills.

Training alone without access to affordable funding will not contribute to informal enterprise growth.

An alternative source of funding with the ease of access of micro-lender financing, but at the rates of commercial bank lending should be investigated. The government can also provide incentives to encourage larger successful enterprises to 'adopt' a micro business to increase their growth potential, as suggested by Smith and Perks (2006:24).
Some informal enterprise managers in Diepsloot indicated that there is not enough space for them to conduct their businesses. Although the result was not a statistically significant growth constraint, the municipality can provide informal enterprises with trading stalls or containers in commercial trading areas as some managers suggested. For this to be successful, a needs analysis should be conducted.

The Diepsloot local municipality can also assist informal enterprises by providing them with proper infrastructure and public services like maintaining communal mobile toilets and providing sewerage facilities, an uninterrupted water supply, and proper roads, streetlights and electricity to ensure the growth of informal enterprises in the township.

Women, who are more prone to sociocultural constraints like crime and discrimination, own more than a third of the informal enterprises in Diepsloot. Security was identified as a growth constraint. Therefore, local authorities should increase security, not only where women operate, but in all areas where informal enterprises operate. Most informal enterprises reported that they were victims of 'break-ins'. The local municipality should deploy security guards at these areas and get the local police at Diepsloot to patrol the area.

\section{Acknowledgement}

The authors appreciate the valuable comments of the two anonymous reviewers.

\section{Competing interests}

The authors have declared that no competing interests exist.

\section{Authors' contributions}

C.M.L. conceptualised the article as part of her masters' research project. J.M.M.V. was the project supervisor and applied a different measure of enterprise growth to the study and structured and added literature and empirical evidence as support.

\section{Funding information}

This research received funding from the University of Johannesburg's Supervisory Linked Bursary.

\section{Data availability statement}

Data sharing is available upon request and approval of request.

\section{Disclaimer}

The views and opinions expressed in this article are those of the authors and do not necessarily reflect the official policy or position of any affiliated agency of the authors. 


\section{References}

Abdi, C.M., 2011, 'Moving beyond xenophobia: Structural violence, conflict and encounters with the "other" Africans', Development Southern Africa 28(5), 691-704. https://doi.org/10.1080/0376835X.2011.623916

Adam, M., 2014, 'Constraints and growth potentials of micro and small enterprises: Case from Mekelle City', Journal of Economics and Sustainable Development 5(24), 133-140.

Alemayehu, Y. \& Gecho, Y., 2016, 'Determinants of micro and small enterprises growth: The case of Durame Town, Kembata Tembaro Zone, Southern Nations and Nationalities and Peoples Region, Ethiopia', International Journal of Business and Nationalities and Peoples Region, Ethiopia', International Journal of Business and
Economics Research 5(5), 161-175. https://doi.org/10.11648/j.ijber.20160505.15

Barron, C., 2000, 'Brilliant ideas but spectacular flops', Sunday Times Business Times, 9 April, 1.

Bear, M., Tladi, S., Pedro, D. \& Bradnum, P., 2005, 'Making retail markets work for the poor - Why and how Triple Trust Organisation decided to intervene in the spaza market in South Africa, case study', The SEEP Network, viewed 10 May 2018, from https://www.findevgateway.org/library/making-retail-markets-work-poor-whyand-how-triple-trust-organisation-decided-intervene.

Berry, T., 2009, 'Challenges and coping strategies of female street vendors in the informal economy', Masters dissertation, Department of Business Administration, University of Pretoria.

Bridge, S., O'Neill, K. \& Cromie, S., 1998, Understanding enterprise, entrepreneurship and small business, Macmillan Business, London.

Brink, A., 1997, The marketing perception of grocery store retailers belonging to black business associations in Gauteng, University of South Africa, Pretoria.

Chandra, V. \& Rajaratnam, B., 2001, Constraints to growth and employment in the informal sector: Evidence from the 1999 informal survey firm, World Bank, Washington, DC.

Chebelyon-Dalizu, L., Garbowitz, Z., Hause, A. \& Thomas, D., 2010, 'Strengthening spaza shops in Monwabisi Park, Cape Town', interactive qualifying project submitted to the faculty of Worcester Polytechnic Institute for the Degree of Bachelor of Science, Worcester, MA.

Chen, M.A., 2012, The informal economy: Definitions, theories and policies, Working Paper No. 1, Women in Informal Employment: Globalizing and Organizing (WIEGO), Manchester.

Cichello, P. \& Rogan, M., 2018. 'Informal-sector employment and poverty reduction in South Africa: The contribution of "informal" sources of income', in F.C.V.N. Fourie (ed.), The South African Informal Sector: Creating jobs, reducing poverty, pp. 226-252, Human Sciences Research Council, HSRC Press, Cape Town.

Co, M.J. \& Mitchell, B., 2006, Entrepreneurship education in South Africa: A nationwide survey. Education and Training 48(5), 348-359.

Creative Research Systems, 2016, viewed 18 December 2017, from https://www. surveysystem.com/sscalc.htm.

Cupido, C., 2002, 'Barriers to entrepreneurship in the Western Cape', MBA Thesis Cape Peninsula University of Technology, Cape Town.

De Beer, J., Fu, K. \& Wunsch-Vincent, S., 2013, The informal economy, innovation and intellectual property - Concepts, metrics and policy considerations, Economic Research Working Paper 1, Economics and Statistics Division, World Intellectual Property Organization, Geneva, viewed 18 December 2017, from https://www. wipo.int/edocs/pubdocs/en/wipo_pub_econstat_wp_10.pdf.

De Graaf, N. \& Flap, H., 1988, 'With a little help from my friends: Social resources as an explanation of occupational status and income in West Germany, the Netherlands, and the United States', Social Forces, 67, 452-472.

Department of Economic Development, 2016, The new growth path: Framework Department of Economic Development, Pretoria, viewed 18 December 2017, from
http://www.economic.gov.za/communications/publications/new-growth-path-series.

Department of Trade and Industry, 2008, Annual review of small business in South Africa 2005-2007, Final Draft 2008, Pretoria.

De Soto, H., 1989, The other path: The invisible revolution in the third world HarperCollins Publishers, New York, NY.

Edusah, S.E., 2013, 'The informal sector, micro-enterprises and small-scale industries: The conceptual quandary', Journal of Economics and Sustainable Development 4(20), 177-186, viewed 18 December 2017, from www.iiste.org.

Erastus, Y.E., Stephen, A.G. \& Abdullai, I., 2014, 'Institutional framework for promoting small and medium scale enterprises in Ghana: Perspective of entrepreneurs.' Australian Journal of Business and Management Research, 3(10), 28-45.

Fadahunsi, A., 2012, The growth of small businesses: Towards a research agenda. American Journal of Economics and Business Administration 4(1), 105-115.

Fatoki, O., 2014, 'Immigrant entrepreneurship in South Africa: Current literature and research opportunities', Journal of Social Science 40(1), 1-7. https://doi.org/10. 1080/09718923.2014.11893297

Fourie, F., 2018a, 'Analysing the informal sector in South Africa: Knowledge and policy gaps, conceptual and data challenges', in F.C.v.N. Fourie (ed.), The South African Informal Sector: Creating jobs, reducing poverty, pp. 3-25, Human Sciences Research Council, HSRC Press, Cape Town.

Fourie, F., 2018b, 'Informal-sector employment in South Africa: An enterprise analysis using the SESE survey', in F.C.v.N. Fourie (ed.), The South African Informal Sector: Creating jobs, reducing poverty, pp. 103-150, Human Sciences Research Council, HSRC Press, Cape Town.

Grabrucker, K., Grimm M. \& Roubaus F., 2018, 'The informal sector in sub-Saharan Africa: A comparative perspective', in F.C.v.N. Fourie (ed.), The South African Informal Sector: Creating jobs, reducing poverty, pp. 48-76, Human Sciences Research Council, HSRC Press, Cape Town.
Grant, R., 2010, 'Working it out: Labour geographies of the poor in Soweto, South Africa', Development Southern Africa 27(4), 596-610. https://doi.org/10.1080/03 76835X.2010.508595

Grimm, M., Knorringa, P. \& Lay, J., 2012, 'Constrained gazelles: High potentials in West Africa's informal economy', World Development 40(7), 1352-1368. https://doi. org/10.1016/j.worlddev.2012.03.009

Hadebe, T., 2010, 'Township home-based enterprises: The case of Pimville', Masters' dissertation, Department of Development Planning, University of the Witwatersrand, Johannesburg.

Hassan, Z.M., 2013, 'Constraints to growth of small and medium enterprises in Zanzibar: The case of urban Westregion', Masters' dissertation, Department of Economic Policy and Planning, Mzumbe University.

ILO (International Labour Organisation), 2009, The informal economy in Africa: Promoting transition to formality: Challenges and strategies, International Labour Organisation, Employment Sector and Social Protection Sector, Geneva.

ILO (International Labour Organisation), n.d., The regulatory framework and the informal economy, viewed 14 June 2019, from https://www.ilo.org/wcmsp5/ groups/public/---ed_emp/---emp_policy/documents/publication/ wcms_210445.pdf

Jütting, J.P. \& Laiglesia, J.R., 2009, Is informal normal? Towards more and better jobs in developing countries, OECD Development Centre, Paris.

Kondowe, C., 2013, 'Exploring the circumstances and experiences of youth immigrants when establishing and running a successful informal micro-business', Master's dissertation, Department of Social Development, University of Cape Town.

Kumar, R., 2012, The regularization of street vending in Bhubaneshwar, India: A policy model, Policy Brief (Urban Policies) No. 7, Women in Informal Employment: Globalizing and Organizing (WIEGO), Cambridge, MA.

Ligthelm, A.A., 2008, 'A targeted approach to informal business development: The entrepreneurial route', Development Southern Africa, 25(4), 367-382. doi: 10.1080/03768350802316138

Lloyd, N. \& Leibbrandt, M., 2018, 'Entry into and exit from informal enterprise ownership in South Africa', in F.C.v.N. Fourie (ed.), The South African Informal Sector: Creating jobs, reducing poverty, pp. 232-249, Human Sciences Research Sector: Creating jobs, reducing povil, HSRC Press, Cape Town.
Councis

Mahajan, S. (ed.), 2014, Economics of South African townships: Special focus on Diepsloot, A World Bank study, World Bank Group, Washington, DC, viewed 18 December 2017, from http://documents.worldbank.org/curated/en/217211468 302413395/Economics-of-South-African-townships-special-focus-on-Diepsloot.

Makaluza, N. \& Burger R., 2018, 'Job-seeker entry into the two-tiered informal sector in South Africa', in F.C.v.N. Fourie (ed.), The South African Informal Sector: Creating jobs, reducing poverty, pp. 178-200, Human Sciences Research Council, HSRC jobs, reducing povert
Press, Cape Town.

Mathieson, J. Popay, J., Enoch, E., Escorel, S., Hernandez, M., Johnson, J. et al., 2008, Social exclusion meaning, measurement and experience and links to health inequalities: A review of literature, WHO Social Exclusion Knowledge Network Background Paper 1, WHO Commission on the Social Determinants of Health, Background Paper 1, WHO Commission on the Soci
Institute for Health Research, Lancaster University.

Mengistae, T., 2014, 'Diepsloot's investment climate', in S. Mahajan (ed.), pp. 178200, World Bank Group, Washington, DC, viewed 18 December 2017, from http:// documents.worldbank.org/curated/en/217211468302413395/Economics-ofdocuments.worldbank.org/curated/en/21721146830

Monkman, D., 2003, A review of DTI's SME financial assistance programmes and its proposal to create a new integrated financial institution, Aanicap Venture Partners, Johannesburg.

Morris, M.H. \& Pitt, L.F., 1995, 'Informal sector activity as entrepreneurship: Insights from a South African township', Journal of Small Business Management 33(1), 78-86.

North, D., 1993, The new institutional economics and development, Econ WPA Economic History. Washington University, viewed 18 December 2017, from http:// www.deu.edu.tr/userweb/sedef.akgungor/Current topics in Turkish Economy/ north.pdf.

Oni, O. \& Fatoki, O., 2013. 'Customer Satisfaction and loyalty to small township retai stores in Mankweng, Limpopo Province, South Africa, Journal of Economics, 4(2), 83-88.

Organisation for Economic Co-operation and Development (OECD), 2003, Annual report, Public Affairs Division, Public Affairs and Communications Directorate, Paris.

Rakabe, E., 2018, 'Prospects for stimulating township economies: A case study of enterprises in two Midrand townships', in F.C.v.N. Fourie (ed.), The South African Informal Sector: Creating jobs, reducing poverty, pp. 285-308, Human Sciences Research Council, HSRC Press, Cape Town.

Rogan, M. \& Skinner C., 2018, 'The size and structure of the South African informal sector 2008-2014: A labour-force analysis', in F.C.v.N. Fourie (ed.), The South African Informal Sector: Creating jobs, reducing poverty, pp. 77-102, Human Sciences Research Council, HSRC Press, Cape Town.

Rogerson, C., 2003, 'Towards pro-poor local economic development: The case for sectoral targeting in South Africa', Urban Forum 14(1), 201-222. https://doi. org/10.1007/s12132-003-0011-z

Rogerson, C.M., 1996, 'Urban poverty and the informal economy in South Africa's economic heart lands', Environment and Urbanization 8(1), 167-179. https://doi. org/10.1177/095624789600800115

Rolfe, R., Woodward, D., Lighthelm, A. \& Guimaraes, P., 2011, 'The viability of informal microenterprises in South Africa', Journal of Developmental Entrepreneurship 16(1), 65-86. 
Rothenberg, A.D., Gaduh, A., Burgera, N.E., Chazalic, C., Tjandraningsihc, I., Radikund R. et al., 2015, 'Rethinking Indonesia's informal sector', World Development 80(C), 96-113.

Rwigema, H. \& Karungu, P., 1999, 'SMME development in Johannesburg's southern metropolitan local council: An assessment', Development Southern Africa 16(1), 1-19. https://doi.org/10.1080/03768359908440064

Sandeep, M., 2014, Economics of South African townships: Special focus on Diepsloot World Bank Group, Washington, DC.

Schoombee, A., 2000, 'Getting South African banks to serve micro-entrepreneurs: An analysis of policy options', Development Southern Africa 17(5), 751-767. https:// doi.org/10.1080/713661429

Smith, E. \& Perks, S., 2006, 'Training interventions needed for developing black microentrepreneurial skills in the informal sector: A qualitative perspective', South African Journal of Human Resource Management 4(1), 17-26. https://doi. org/10.4102/sajhrm.v4i1.85

Sparks, D.L. \& Barnett, S.T., 2010, 'The informal sector in sub-Saharan Africa: Out of the shadows to foster sustainable employment and equity?', International Business \& Economics Research Journal 9(5), 1-12. https://doi.org/10.19030/iber. v9i5.563
Statistics South Africa, 2017, Quarterly labour force survey: Quarter 3: 2017 (July to September), Statistics South Africa, Pretoria, viewed 10 May 2018, from http:// www.statssa.gov.za/.

The South African Presidency, 2008, The impact of crime on small business, Small Business Project (SBP), Johannesburg.

Ukukhula Business Solution, 2003, Informal trading policy and management framework, City of Cape Town, Cape Town.

USAID (United States Agency for International Development), 2005, Understanding micro and small enterprises growth, Micro reports no. 36, viewed 18 December 2017, from http://www.microLINKS.org.

Welter, F., Smallbone, D. \& Pobol, A., 2015, 'Entrepreneurial activity in the informa economy: A missing piece of the entrepreneurship jigsaw puzzle', Entrepreneurship
\& Regional Development 27(5-6), 292-306. https://doi.org/10.1080/08985626.2 \& Regional Deve

Willemse, L., 2011, 'Opportunities and constraints facing informal street traders: Evidence from four South African cities', Town and Regional Planning 59, 7-15.

Woodward, D., Rolfe, R., Lighthelm, A. \& Guimaraes, P., 2011, 'The viability of informal microenterprises in South Africa', Journal of Developmental Entrepreneurship 16(1), 65-86. https://doi.org/10.1142/S1084946711001719 